\title{
Pengembangan Sistem Informasi Desa bagi Pembangunan Kesehatan Perempuan
}

\author{
Tri Hastuti Nur R, Hajar Nur Setyowati, Siti Noordjannah Djohantini \\ 1 Dosen Prodi Ilmu Komunikasi, Universitas Muhamamdiyah Yogyakarta \\ 2 Peneliti Lembaga Penelitian dan Pengembangan Pimpinan Pusat 'Aisyiyah \\ 3 Dosen Prodi Manajemen, Universitas Muhammadiyah Yogyakarta \\ Email: trinur@umy.ac.id \\ DOI: $10.18196 / p p m \cdot 34 \cdot 275$
}

\begin{abstract}
Sistem Informasi Desa (SID) merupakan salah satu mandat dalam UU Desa No 6 Tahun 2014 tentang Desa untuk mendukung tata kelola pembangunan desa. Namun demikian SID ini masih banyak dipahami secara kurang tepat oleh perangkat desa maupun masyarakat desa yaitu sebagai sebuah produk sistem informasi semata, padahal SID dapat meningkatkan kualitas pembangunan desa, khususnya pada pembangunan kesehatan dan pemberdayaan perempuan berbasis data dengan mengedepankan prinsip partisipatif dan adil gender. Arus utama yang banyak terjadi di desa bahwa pembangunan dalam bidang kesehatan dan pemberdayaan perempuan masih belum menjadi prioritas. Merespon kondisi tersebut maka dilakukan pendampingan pengembangan SID dengan menggunakan pendekatan perspektif gender dan partisipatif di desa Kalibening, kecamatan Dukun, Magelang. Metode yang dilakukan diawali dengan need assessment, workshop SID dan perencenaan desa, workshop partisipat if penyusunan peta desa, penyusunan instrumen dan monev. Hasil dari pendampingan yang telah dilakukan adalah bahwa pengembangan manajemen SID secara partisipatif dan berpihak pada perempuan, berdampak pada ketersediaan data dan informasi desa yang sesuai dengan kondisi sosial ekonomi dan budaya desa serta kebutuhan maupun potensi perempuan di desa tersebut. Selain itu, integrasi data Program Indonesia Sehat dengan Pendekatan Kelvarga ke dalam SID dapat meningkatkan kualitas perencanaan pembangunan desa berbasis data.
\end{abstract}

Keywords : Sistem Informasi Desa, pembangunan kesehatan, pemberdayaan perempuan

\section{Pendahuluan}

Lahirnya UU Desa Nomor 6 tahun 2014 menjadi acuan sekaligus rekognisi pengembangan Sistem Informasi Desa (SID). Beberapa pasal yang menjadi rujukan antara lain pasal 24, pasal 26, pasal 27, pasal 68 dan pasal 86. Merujuk pada beberapa pasal di atas bahwa UU Desa mengamanatkan keterbukaan informasi publik antara lain melalui pelembagaan SID di tingkat desa. Kebijakan tersebut sejalan dengan amanat UU Nomor 14 tahun 2008 tentang Keterbukaan Informasi Publik. Desa sebagai salah satu lembaga publik memiliki tanggungjawab dan orientasi pada pelayanan masyarakat sebagai upaya pelaksanaan good governance di tingkat desa (Sedarmayanti, 2004). Pengembangan SID merupakan strategi pembangunan pemerintah desa dalam mendukung good governance dan meningkatkan kesejahteraan masyarakat. Tahapan pembangunan desa menjadi ruang strategis bagi perempuan untuk terlibat dengan memperhatikan situasi, kebutuhan, dan potensi masyarakat berbasis data sehingga kebijakan pembangunan desa mempunyai visi keadilan gender dan inklusi social (Wahyudin, 2015)

Dalam struktur masyarakat desa, kelompok perempuan dan marginal sering terlewatkan dalam proses pembangunan desa khususnya pengambilan kebijakan publik. Rendahnya partisipasi perempuan bukan karena perempuan tidak mau, melainkan karena dianggap sudah diwakili oleh perempuan elite desa atau suami. Perwakilan perempuan mungkin hadir dalam 
pertemuan-pertemuan di desa, tetapi mereka tidak dapat menyampaikan gagasan (partisipasi semu). Target Pembangunan Berkelanjutan (SDGs) mencakup pencapaian 'kesetaraan gender dan menguatkan semua perempuan dan gadis. Strategi untuk mencapai kesetaraan gender dengan pengarusutamaan gender dalam proses pembangunan.

Masyarakat desa berhak mendapatkan informasi dari Pemerintah Desa serta mengawasi kegiatan penyelenggaraan Pemerintahan Desa, pelaksanaan Pembangunan Desa, pembinaan kemasyarakatan Desa, dan pemberdayaan masyarakat Desa (Sasmita, 2006, 2013). Untuk menjembatani kewajiban pemerintah desa di satu sisi dan hak masyarakat desa di sisi lain harus dipenuhi, di sinilah pentingnya Sistem Informasi Desa (SID). Sistem Informasi Desa merupakan sistem yang bertujuan untuk mengelola sumber daya desa sebagai dasar dalam perencanaan pembangunan desa yang partisipatif, akuntabel, dan responsif gender dan dapat menopang penyelenggaraan pemerintahan desa secara efektif dan efisien. Dalam sistem ini apa yang dimiliki oleh pemerintah desa dan masyarakat desa bertemu dalam bentuk data desa yang diolah dan menjadi acuan perencanaan pembangunan desa. Untuk memperoleh data yang signifikan dibutuhkan partisipasi laki-laki maupun perempuan dan berbagai unsur masyarakat.

Program ini dilaksanakan dengan model di desa Kalibening, kecamatan Dukun kabupaten

Magelang Jawa Tengah. Tujuan dari pengembangan SID adalah mengembangkan model pengelolaan SID dengan pendekatan partisipatif dan gender perspektif.

\section{Metode Pelaksanaan}

Pelaksanaan program dengan menggunakan pendekatan partisipatif, inklusif, dan gender perspektif. Pendekatan ini penting sekali agar proses pengembangan Sistem Informasi Desa sebagai bagian dari pembangunan desa memperhatikan keterwakilan perempuan dan kelompok minoritas (kelompok miskin dan diffable) yang selama ini jarang didengarkan suaranya. Mereka dilibatkan dalam penyusunan instrumen SID dan menetapkan indikatorindikator bersama dalam sebuah forum di tingkat desa. Selain partisipasi perempuan dan kelompok minoritas lain, data-data yang terkait dengan isu-isu perempuan dimasukkan dalam SID menjadi bagian yang terintegrasi dengan data-data desa yang sudah ada. Selama ini datadata yang ada di desa merupakan data yang tidak terpilah gender dan tidak memperhatikan kebutuhan perempuan.

Dari sisi langkah-langkah pelaksanaan kegiatan metode implementasi program diawali dengan melakukan pemetaan kebutuhan (need assessment) untuk memetakan kebutuhan dalam pengelolaan SID, potensi yang sudah dimiliki, data-data yang sudah tersedia, kelompok yang akan dilibatkan. Setelah need assessment kemudian dilakukan workshop penyusunan desain SID; melakukan penyusunan instrumen pendataan SID; pengumpulan dan pengolahan data SID; pengembangan website desa; dan pemanfaatan SID dalam perencanaan pembangunan sekaligus monev. Proses pelaksanaan kegiatan pengembangan SID ini membutuhkan waktu yang agak panjang dikarenakan harus mengedepankan prinsip partisipatif dan pemberdayaan sehingga desa memiliki kemampuan untuk melanjutkan dan mengelolannya secara mandiri. 


\section{Hasil dan Pembahasan}

Dalam mengembangkan Sistem Informasi Desa yang partisipatif dan responsif kesehatan ibu dan anak, terdapat beberapa langkah strategis yang harus dilakukan. Pertama, Serial workshop perencanaan desain SID; kedua, identifikasi data desa yang diperlukan dan penyusunan instrumen pendataan; ketiga, pengumpulan dan pengolahan data secara partisipatif; keempat, pengembangan website dan sistem informasi pendataan desa; kelima, pemanfaatan SID sebagai basis perencanaan pembangunan desa.

Pertama, Workshop penyusunan desain SID. Meski SID menjadi mandat dalam UU Desa namun belum semua pihak di desa memahami tentang Sistem Informasi Desa. Tidak sedikit yang memandang SID sebagai sistem informasi semata terkait pendataan atau cukup dengan membuat website tentang desa. Oleh karena itu, perlu dilakukan workshop penyusunan desain SID yang melibatkan pemerintah desa dan multi pihak di desa yang nantinya akan berperan dalam pengembangan SID, yaitu pemdes desa Kalibening, kader, organisasi perempuan di desa termasuk 'Aisyiyah, tokoh masyarakat dan tokoh agama, hingga BPD. Pelibatan multi pihak ini menjadi penting untuk memastikan bahwa pengembangan SID bersifat partisipatif.

Dalam workshop ini, dijelaskan perihal SID dan pembangunan yang responsif gender. Sesi penting lainnya dalam workshop penyusunan desain adalah peserta diminta untuk mendiskusikan mimpi desa selama 10 tahun ke depan sebagai gambaran visi dan misi pembangunan desa. Dari hasil diskusi yang dilakukan secara berkelompok ini, teridentifikasi mimpi atau harapan warga pada desa kalibening, yaitu sebagai desa wisata; BUMDES berkembang; desa melek internet; desa layak anak; desa sehat peduli pada kesehatan reproduksi; kesetaraan gender di desa; dan desa sejahtera tanpa kemiskinan. Selanjutnya, peserta diminta mendiskusikan usulan program dan data yang dibutuhkan berdasar dari mimpi pembangunan desa.

Gambar 1

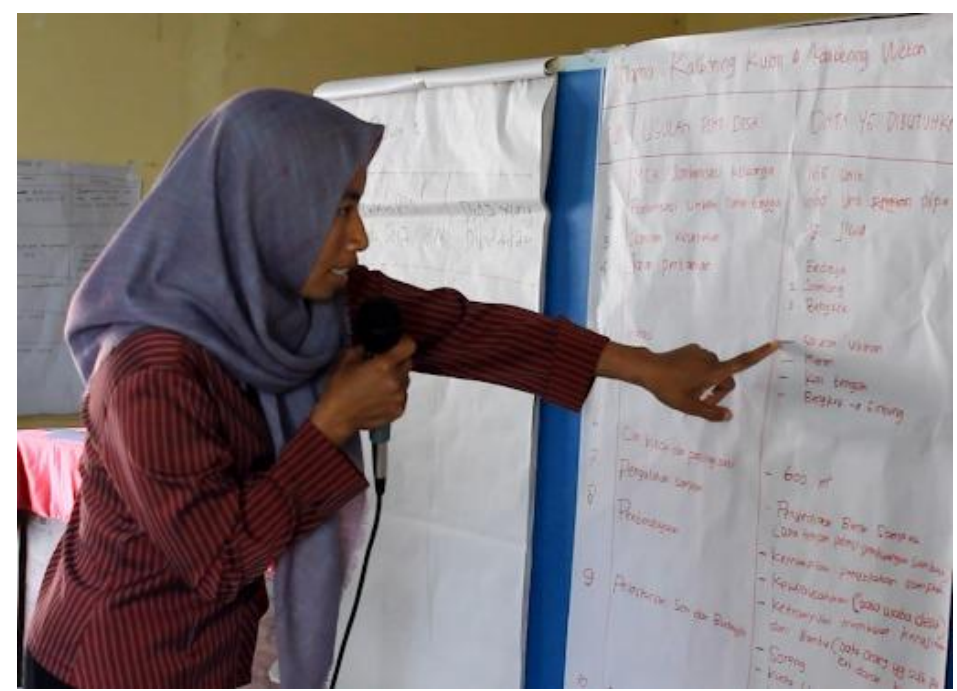

Ket: Kader 'Aisyiyah sedang menyampaikan mimpi tentang desa yang sehat dan adil gender 
Kedua, penyusunan instrumen pendataan SID berdasarkan kebutuhan pembangunan desa yang telah diidentifikasi pada workshop penyusunan desain SID. Terdapat beberapa poin pendataan, yaitu pendataan kesejahteraan. Problem validitas data antara lain disebabkan penentuan kriteria miskin yang belum tentu sesuai dengan kondisi masyarakat desa. Oleh karena itu, dalam pengembangan SID ini dilakukan penentuan kembali tingkat kesejahteraan keluarga berdasarkan indikator kesejahteraan sesuai dengan kondisi desa.

Selain pendataan kesejahteraan, ditentukan unsur dalam pendataan kesehatan. Data kesehatan ini menjadi penting karena salah satu ciri khas dari pengembangan SID di desa Kalibening yaitu responsif kesehatan khususnya kesehatan ibu dan anak sesuai dengan visi pembangunan desa sehat. Dalam pendataan kesehatan ini, nantinya muncul pengembangan dengan mengintegrasikan data PISPK (Program Indonesia Sehat Pendekatan Keluarga) ke dalam SID karena selama ini belum menjadi dasar dalam pembangunan desa. Pendataan desa mencakup pula pendataan khusus sosial, ekonomi, dan budaya.

Ketiga, pengumpulan dan pengolahan data. Proses pendataan dilakukan pada 926 KK di 9 dusun, yaitu Gendungan, Argosono, Cepek, Ngentak, Gintung, Kalibening Kulon, Kalibening Wetan, Windusari, Demo. Selain itu, dilakukan pengambilan gambar wilayah menggunakan drone. Luas desa Kalibening sendiri sebesar 275,67 Ha. Hasil dari pengambilan gambar digunakan untuk melakukan validasi data kesejahteraan keluarga dan membantu menentukan titik koordinat untuk penyajian data desa dalam website desa Kalibening.

Selanjutnya dilakukan pengolahan data, yaitu klarifikasi data khususnya data kesejahteraan, penilaian data kesejahteraan berdasarkan pedoman indikator kesejahteraan keluarga. Proses diskusi dalam me-review tingkat kesejahteraan ini menjadi dinamis ketika melibatkan pula perempuan yang mengetahui lebih mendalam kondisi keluarga berdasarkan interaksi seharihari.

Keempat, mengembangkan website dan sistem informasi yang memuat hasil pendataan desa. Materi website desa www.kalibening.id meliputi visi misi desa, program pembangunan desa, hasil pembangunan, desa sehat, layanan dasar pemdes, dokumen pembangunan, dan katalog produk desa. Selain itu diupayakan terdapat ruang data yang bersifat internal untuk menyimpan data dan memperbarui data desa. Supaya proses pengelolaan SID ke depannya dapat dilakukan secara mandiri oleh tim pembaharu desa, maka dilakukan pelatihan pengelolaan website dan sistem informasi data desa dengan multi pihak.

Kelima, pemanfaatan SID dalam perencanaan pembangunan desa. Hasil dari pengembangan SID disimulasi sebagai basis perencanaan pembangunan desa, sebagaimana menjadi salah satu tujuan pengembangan SID. Proses ini juga dapat menjadi bagian dari evaluasi dan pembelajaran dari pengembangan SID.

\section{Simpulan}

Catatan penting dari hasil program adalah pertama, pelibatan perempuan dalam pengembangan SID sebagai bagian dari pembangunan desa merupakan sebuah keharusan dikarenakan amanat UU dan mendengarkan kebutuhan perempuan sebagai anggota 
masyarakat. Kedua, pelibatan perempuan dalam pengembangan SID membutuhkan proses yang lebih lama dikarenakan penting membangun kesadaran bersama antara perangkat desa dan bahkan perempuan sendiri pentingnya mereka terlibat dalam pengembangan SID sebagai dasar untuk perumusan kebijakan di tingkat desa, dan ketiga, pendekatan pemberdayaan sangat penting meskipun membutuhkan proses yang lebih lama namun keberlanjutan program akan terjaga.

\section{Ucapan Terima Kasih}

Kepala Desa Kali Bening bapak Nurbiyanto dan seluruh perangkat desa kecamatan Dukun kabupaten Magelang propinsi Jawa Tengah

Masyarakat dan kader-kader desa Kalibening

Bidan Desa di desa Kalibening

Pimpinan Pusat 'Aisyiyah, Pimpina Daerah Aisyiyah kabupaten Magelang, PCA Dukun dan Pimpinan Ranting Aisyiyah (PRA) desa Kalibening.

DFAT Australia Embassy

Mas Budi Hermanto dan mas Widodo dari Masyarakat Peduli Media Yogyakarta

\section{Daftar Pustaka}

Adisasmita, Rahardjo. 2006. Pembangunan Pedesaan dan Perkotaan. Yogyakarta: Graha Ilmu

Adisasmita, Raharjo. 2013. Pembangunan Pedesaan; Pendekatan Partisipatif, Tipologi, Strategi, Konsep Desa Pusat Pertumbuhan, Yogyakarta, Graha Ilmu.

Andriyana (2015), Perencanaan Pembangunan Partisipatif di Desa Betong Kecamatan Balaesang Tanjung kabupaten Donggala , e-Jurnal Katalogis, Volume 3 Nomor 8, Agustus 2015.

Kessa, Wahyudin, Perencanaan Pembangunan Desa.(2015) Jakarta, Kementerian Desa, Pembangunan Daerah Tertinggal, dan Transmigrasi Republik Indonesia, Jakarta.

Sedarmayanti. (2004). Good Governance (Kepemerintahan Yang Baik), Cetakan Kedua, Bandung, Mandar Maju.

Undang-Undang nomor 6 tahun 2014 tentang Desa

Undang-Undang nomor 14 tahun 2008 tentang Keterbukaan Informasi Publik. 